\title{
A Survey of the Literature on the Effect of Family Ownership on Capital Structure
}

\author{
Zien Huang 1,*, Suyuan Fan², Shangqi Wang ${ }^{3}$ \\ ${ }^{1}$ Carey Business School, Johns Hopkins University, Baltimore, USA, zh86@nau.edu \\ ${ }^{2}$ Lancaster University Management School, Lancaster University, UK, \\ ${ }^{3}$ Chongqing Technology of University, Chongqing, China
}

\begin{abstract}
As one of the major business participants, compare to others, family-owned firms are unique due to its special ownership structure, management style, and financing needs. Moreover, how to balance its debt and equity to create the best capital structure for the growth of the company is an interesting academic research topic. Therefore, the purpose of this paper is to review the related literature to find out the connection between family ownership and capital structure. This paper first reviews the theoretical background between family ownership and capital structure and then conducts an empirical test based on the empirical test of Anderson et al. Finally, conclude that generally, the magnitude of proportion that family takes in the company positively support the effectiveness of family ownership because of the decrease in coast of debt. However, the precisely magnitude of family ownership proportion and the underlying concept about the effectiveness of family ownership need to be discussed.
\end{abstract}

Keywords: Capital structure, family ownership, debt financing.

\section{INTRODUCTION}

From 1958 with the exhibition of Modigliani and Miller's research, capital structure's study experienced an enormous development over the years. During the years, capital structure research was mainly focused on large companies and ignored the importance of other form of business. However, as one of the major contributors to the global market, family-owned firms need more attention. According to the Family Firm Institute statistical analysis, two-thirds of all businesses are family-owned firms which generate 70 percent of annual global GDP. As the European Commission reported, in Europe, family businesses involve in all industries, which include 60 percent of companies and produce 40 to 50 percent of job opportunities. Therefore, this paper decides to collect information about the literature of the effect of family ownership on capital structure, to provide further insights in this research gap area.

This first section of this paper is the theoretical summary, which will give some background information about family ownership and the related capital structure theory. Second is the empirical literature summery, where we focus on the empirical test of Anderson et al. and try to clarify their results through doing a reassembly empirical test with a smaller sample [1]. The third part is the discussion part where we compare Anderson et al.'s paper with Villalonga and Anit's paper and discuss how family ownership can affect capital structure [2].

\section{THEORETICAL SUMMARY}

Family ownership is where families represented on the board of directors or involve in the management, for example, the founder CEO is both the current CEO and member of the board of director. As mentioned in European Commission family ownership has three common factors. Firstly, natural person owns major decision-making rights [3]. Secondly, among all the voting rights, $25 \%$ are belong to founder or descendants. Lastly, the whole process of the governance of the firm should include at least one representative of the family. The amount of family ownership is not rare in the company capital structure. Refer to Shleifer and Vishny there are 149 family ownership corporations out of 456 of Fortune 500 corporations in 1980 [4].

Although family ownership takes a noticeable proportion in the business world, the effectiveness of this company structure is not always strong. The effectiveness of family ownership varies when they combined with different management mode [5]. Concentrated ownership itself will not affect the firm's productivity instead it is who runs the firm matter. 
Therefore, even though family-owned company with outside manager is equally productive with non-familyowned firm, the production will be deceased when it operates by owner manager. Their results show that family ownership with outside managers will perform better than family-owned firm with owner managers. However, Villalonga and Amit find that under certain types of family control and management, family ownership will create value [2]. Besides, if family control higher than ownership shareholder's value will be decreased. In the case of family ownership what will be faced by minority shareholders is that whether a CEO is a founder or a descendant. Because evidence shows that founder manager would make contribution to the value of the company while descendant would not. More specifically, Anderson and Reeb research on how company performance would influent family ownership [6]. They conclude that family firms perform better than non-family firms when the percentage of family ownership is less than $30 \%$. If the percentage is higher than $30 \%$ the performance would decrease as the increase of family ownership. When family members serve as CEOs, the company will perform better than with outside CEO does.

It is reasonable to suppose that it may be the management manipulation that leads to the performance difference when the proportion of family ownership takes in company varies. When the firm deeply controlled by the family, it has the greatest potential to experience entrenchment and poor performance. Comparing to dispersive shareholders, controlling shareholders may have different incentive structures and they may seek to extract private benefits from the firm [7]. Therefore, the involving of outsiders is an effective way to minimize family manipulations. Although Family control raises conflicts between the family and minority shareholders when shareholders do not take the control right, family ownership reduces the agency problem between owners and managers at the same time [8]. Evidence shows that family ownership better protects bondholders' interests [1]. When family ownership takes $12 \%$ of the company, the company's gain will be highest, and when family member works as the CEO, the cost of debt financing of the company is higher than that with outside CEO.

There might be some linkage between Anderson et al.'s finding and capital structure theory. Based on one of the major capital structure theories, pecking order theory, equity finance is at the bottom of the financing list because companies would only issue equity when they have bad information to avoid undervaluation of the firm [9]. Therefore, the involving of family ownership decreases the agency cost of debt is in line with the pecking order theory, as the lower the agency cost of debt the more willingness of the company to issuing debt. Additionally, because of the higher continuity and stability of family firms, they have the capacity of having higher leverage [10]. Hence, we may suggest that the family ownership has a more efficient management of resources; therefore, they are more capable to have financial leverage.

\section{EMPIRICAL LITERATURE SUMMARY}

\subsection{Survey focus}

In one of the papers, by using agency cost of debt as a bridge, Anderson et al. studied how family ownership affects firms' capital structure [1]. The paper claims that founding family ownership can lower the cost of debt financing in large, publicly traded firms so that the company with higher family ownership may be more possible to issue debt for external finance. To prove their suggestion, the author collected 252 S\&P 500 firms' data to do a comprehensive empirical analysis. After controlling all other variables which can affect debt costs, founding-family incentive structures being pointed out as the factor to limit agency problems between equity holders and debt holders, leading debt yield spreads to decrease. Since the data using in the paper came from 2003 and market and economic environment have enormous changes after that, we are curious that whether the same results can be tested out using the same statistic methods, but data from current years instead.

\subsection{Data introduction}

In the original paper, the authors collected three categories of data, corporate bonds, ownership structure as well as board representation, and firm-specific financial situations. They collected market value, coupon, yield and credit rating of corporate bonds from the Lehman Brothers Bond Database (LBBD) and the S\&P 500 Industrial Index. However, because Lehman Brothers went bankruptcy in 2018 and the database closed after that, so, we cannot reach out this resource. Instead, we collected data on firms from Financial Industry Regulatory Authority (FINRA). Despite of these, the other information related to family ownership and companies' finance are both came from the same sources compared to the original papers, which were proxy statements and the companies' annual report (10K). We randomly picked 30 firms from the S\&P 500 lists for our test.

\subsection{Measuring the cost of debt financing}

We used the yield spread (Spread) to measure the cost of debt financing. The yield spread is calculated by the firm's outstanding traded debt's weighted-average yield to maturity yield subtracts to the maturity on a Treasury security with corresponding duration. Duffie introduced this method which commonly used in the subsequent fixed-income research to estimate the debt risk premium [11]. We defined a corporate debt security's yield as the present value of the future cash flows divided by the security's price. We set the yields 
on Treasury securities equal to the Treasury yield of 3month T-bill.

\subsection{Control variables}

Since family ownership can potentially negatively affect the cost of debt from different perspectives, for example, the increasing family ownership can help the owners get more power to control the company, therefore, the company may gain more freedom in operation instead of balancing benefits across different parties. This may enhance the company's performance so that the company can generate more cash flows to repay current debt so that limit the potential default risk. Considering all the influenced factors, to test how family ownership can influent the agency cost of debt, firm performance, cashflow volatility, leverage level, form size, debt duration, debt credit ratings, and debt liquidity were introduced in the paper as the control variables. All the variables' calculations are shown in the tables.

\subsubsection{Control variable measures:}

A. Firm perform is measured as the ratio of cash flows (net income plus depreciation and amortization) to total assets. That is

Perform $=\frac{\text { Cashflow }}{\text { Assets }}$

B. Firm risk (Risk) is the standard deviation of the firm's cash flows scaled by long-term debt for the previous 5 years. That is
Risk $=\sqrt{\frac{\sum\left\{\left(\frac{\text { Cashflow }}{D e b t}\right)-\left(\frac{\text { Cashflow }}{D e b t}\right)_{a v g}\right\}^{2}}{n-1}}$

C. Leverage is the ratio of long-term debt to total capital. That is

Leverage $=\frac{\text { Debt }}{\text { (Debt }+ \text { Equity })}$

D. Firm size is measured as the natural log of the debt and equity of the firm. That is

Size $=\operatorname{Ln}($ Debt + Equity $)$

E. Duration is used to control for differences in maturity and coupon of the firm's outstanding debt. And it is the Macaulay duration. That is

$$
D U R=\sum_{t=1}^{K} \frac{t X C F_{t}}{P(1+Y)^{t}}
$$

F. Credit Ratings (Rating) is used to control for different in default risk. As in Reeb et al. [12], we use the average of Moody's and S\&P credit ratings to measure the default risk premium. Bond ratings are computed using a conversion process in which $\mathrm{AAA}+$ rated bonds are assigned a value of 23 and D rated bonds receive a value of 1 .

\begin{tabular}{lcc} 
& Table 1: Bond rating numerical conversions & \\
\hline Conversion number & Moody's rating & S\&P 500 ratings \\
\hline 23 & Aaa & AAA+ \\
\hline 22 & Aaa & AA+ \\
\hline 21 & Aa1 & AA \\
\hline 20 & Aa2 & AA- \\
\hline 19 & Aa3 & A+ \\
\hline 18 & A1 & A \\
\hline 17 & A2 & A- \\
\hline 16 & A3 & BBB+ \\
\hline 15 & Baa1 & BBB \\
\hline 14 & Baa2 & BBB- \\
\hline 13 & Baa3 & BB+ \\
\hline 12 & Ba1 & BB \\
\hline 11 & Ba2 & BB- \\
\hline 10 & Ba3 & B \\
\hline 9 & B1 & B \\
\hline 8 & B2 & B- \\
\hline 7 & B3 & CCC+ \\
\hline 6 & Caa1 & CCC \\
\hline 5 & Caa2 & CCC- \\
\hline 4 & Caa3 & CC \\
\hline 1 & Ca & D \\
\hline & C & D \\
\hline
\end{tabular}




\subsection{Descriptive statistics}

Table 2 illustrates the descriptive statistic for all the control variables. Mean, median, standard deviation, minimum, and maximum values are listed separately.

Table 2 Sample description of variable measures

\begin{tabular}{lcccc}
\hline Variable & Mean & Std, Dev. & Min & Max \\
\hline Spread (basis points) & 187.840 & 72.401 & 89.000 & 420.800 \\
FamFirm & 0.400 & 0.498 & 0.000 & 1.000 \\
Duration & 1.003 & 0.130 & 0.728 & 1.269 \\
Rating & 16.350 & 3.182 & 10.000 & 12.000 \\
Size & 10.139 & 2.219 & 0.894 & 13.060 \\
Age & 11.233 & 3.631 & 3.409 & 18.007 \\
Leverage & 0.487 & 0.262 & 0.116 & 1.214 \\
Risk & 0.229 & 0.297 & 0.016 & 1.214 \\
Performance & 0.124 & 0.069 & 0.012 & 0.276 \\
\hline
\end{tabular}

According to the results, the average yield spread of debt beyond the Treasury yield is 188 basis points, and its standard deviation is very high, close to 73 basis points. We set the family ownership measure (FamFirm) as a binary variable, meaning that FamFirm is either one (family firm) or zero (non-family firm). As we can see, in our sample, family firms comprise $40 \%$. Firm size is measured as the natural log of total debt and equity (in millions), with a mean of $\$ 10.14$, a standard deviation of $\$ 2.21$, and a maximum of $\$ 13.05$ and a minimum of $\$ 0.89$, respectively. Firm performance has an average of $12.4 \%$ is calculated by cash flows divided by total assets. The traded debt has a mean duration approximately 1 years, a standard deviation close to 0.13 years, in addition, a maximum duration nearly 1.27 years. Moreover, the debt has been outstanding for 11.23 years on average, with a maximum outstanding for 18 years. The leverage ratio has a mean of $48.67 \%$, and its standard deviation is $26.17 \%$.

Compare to the original results, the companies we tested generally have more family-owned firms included (mean $40 \%$ to $30 \%$ ). Besides, the leverage ratio shown that the companies we tested issue more debt (mean $48.7 \%$ to $21.9 \%$ ) so that they would be more risk to fulfil the debt obligations (mean $22.9 \%$ to $0.03 \%$ ).

\subsubsection{Anderson (2003) test resuls}

Table 3 Sample description of variable measures

\begin{tabular}{lcccc}
\hline Variable & Mean & Std, Dev. & Min & Max \\
\hline Spread (basis points) & 135.961 & 109.454 & 2.239 & 1067.866 \\
FamFirm & 0.300 & 0.459 & 0.000 & 1.000 \\
Duration (years) & 6.287 & 2.454 & 0.083 & 13.621 \\
Rating & 15.979 & 3.209 & 1.000 & 22.143 \\
Size (firm) & 8.877 & 1.28 & 4.389 & 12.782 \\
Age (bond age) & 3.917 & 2.689 & 0.033 & 25.655 \\
Leverage & 0.219 & 0.133 & 0.000 & 0.943 \\
Risk & 0.030 & 0.035 & 0.002 & 0.274 \\
Perform & 0.138 & 0.075 & -0.119 & 0.786 \\
\hline
\end{tabular}


Table 4: Yield spread and family ownership

\begin{tabular}{lc}
\hline & \\
Spread & Coef. \\
\hline FamFirm & -5.584 \\
Duration & 1.379 \\
Rating & -14.126 \\
Size & -12.354 \\
Age & 5.086 \\
Leverage & 0.640 \\
Risk & 3.792 \\
Perform & -2.761 \\
\hline
\end{tabular}

\subsection{Multivariable testing results}

In the primary specification,

$$
\begin{aligned}
\text { Spread }_{i, t}=A_{0} & +A_{1}\left(\text { FamFirm }_{1, t}\right) \\
& +A_{2}\left(\text { Duration }_{i, t}\right)+A_{3}\left(\text { Credit }_{i, t}\right) \\
& +A_{4}\left(\text { Size }_{1, t}\right)+A_{5}\left(\text { Leverage }_{i, t}\right) \\
& +A_{6}\left(\text { Leverage }_{1, t}\right)+A_{7}\left(\text { Risk }_{i, t}\right) \\
& +A_{8}\left(\text { Performance }_{1, t}\right)+\varepsilon
\end{aligned}
$$

we followed the paper to examine the cross-sectional relation between family ownership and the cost of debt financing, and various control variables. In this formula, we use spread to represent the bond yield beyond the Treasury yield with corresponding maturity. All the independent variables in our regression have showed in our previous descriptive variables section, including family ownership (FamFirm), Duration, Credit, Size, Age, Leverage, Risk, and Performance. In Anderson et al. [10], the authors get the results which suggest that A1 (family ownership coefficient estimator) is a negative coefficient, which supports that their hypothesis of family ownership is correct. Therefore, family ownership can reduce the agency costs of debt. However, from our results, considering our test results (Table 5), Anderson's testing result does not appear to be robust.

Table 5 Yield spread and family ownership

\begin{tabular}{lcccccc}
\hline & \multicolumn{3}{c}{ Robust } & & & \\
Spread & Coef. & Std. Err. & $\mathrm{t}$ & $\mathrm{P}>|\mathrm{t}|$ & \multicolumn{2}{c}{$95 \%$ Conf. Interval } \\
\hline FamFirm & 1.502225 & 13.85843 & 0.11 & 0.915 & -27.31797 & 30.32242 \\
Duration & -149.625 & 51.17347 & -2.92 & 0.008 & -256.046 & -43.20393 \\
Rating & -12.5896 & 2.661604 & -4.73 & 0.000 & -18.12471 & -7.054494 \\
Size & 4.432669 & 3.937556 & 1.13 & 0.273 & -3.755927 & 12.62127 \\
Age & 12.1421 & 1.922014 & 6.32 & 0.000 & 8.145053 & 16.13915 \\
Leverage & 12.22737 & 34.03944 & 0.36 & 0.723 & -58.56152 & 83.01626 \\
Risk & 23.03804 & 33.44943 & 0.69 & 0.499 & -46.52387 & 92.59994 \\
Perform & -188.0815 & 89.25321 & -2.11 & 0.047 & -373.6937 & -2.469279 \\
_cons & 373.8706 & 71.39028 & 5.24 & 0.000 & 225.4064 & 522.3348 \\
\hline
\end{tabular}

Because from our regression results, family ownership is not a significant variable under the $95 \%$ confident interval. And it is obvious that the coefficient is positive. Therefore, by replicating the study with newer data we found out that the results may change because of the data differences.

The results' differences can potentially be explained in several ways. First, during the 18 years, the market and economic conditions being changed a lot, companies have been issues numerous new strategies and adjust their capital structure to fit the new environment. Second, the companies in our dataset are generally in new-tech industries, for example, Apple, Amazon, Dell, and Ebay. However, the original paper focus more on traditional industries, for example, construction, wholesale trade, and manufacturing. The specific characteristics among industries may create distinctions. Finally, the sample size we used is 30 instead of 252, the original paper included more data into consideration.

In this case, Anderson's paper provides us a good perspective to think about how family ownership can affect company's capital structure, which is by 
considering the relationship between family ownership and the agency cost of debt. However, under current circumstance, we still need to do more replicated tests to find the results in the future.

\section{OTHER PAPER}

During our research, we found out that Villalonga and Amit [4] provides a more conservative theory compare to Anderson et al. [10]. Rather than only considering family ownership itself, Villalonga and Amit [4] divides family ownership into three parts, family ownership, control, and management. In Villalonga and Amit's paper [4], only when the founder of the company is the CEO of the firm, family ownership can create value. Other than that, a costly owner-manager conflict would create, and which could destroy firms' value. They argue that family control and family management should be discussed separately and since Anderson et al. [10] does not separately discuss family ownership the results may be impropriated. By using data, Villalonga and Amit's group examine the impact of family ownership, control, and management to firm value. And the results highlighted that family ownership can only create when it is combined with certain levels of family control and management. Therefore, when considering the relationship between family ownership and capital structure, we may need to research the differential contribution create by different family ownership's elements to capital structure.

\section{CONCLUSION}

In the paper, we first indicate the definition of family ownership and the importance of it to current business world, and then we regard company performance as a bridge to link family ownership and capital structure, discussing the main thoughts from Barth et al. [3], Villalonga and Amit [4] and Anderson and Reeb [6] to get the idea of how family ownership and capital structure relate. According to our research, the magnitude of proportion that family takes in the company positively support the effectiveness of family ownership. Therefore, we suggest the reason for this is because the controlling family shareholders' interest is different from minority shareholders but correspond to bondholders' interest.

Then, we decide to focus on the conclusion of Anderson et al.'s [10] that family ownership would increase finance leverage through lower the agency cost of debt, and we process our empirical summary based on Anderson et al. Since the data using in Anderson et al.'s paper came from 2003 and market and economic environment have enormous changes after that, we decide to check whether the same results can be tested out using the same statistic methods, but data from current years instead. Rather than choosing 252 firms from $500 \mathrm{~S} \& \mathrm{P} 500$ firms we randomly select 30 firms from S\&P 500 firms and follow the same empirical logic as Anderson et al. However, our test results are contradictory from Anderson et al.'s results, where we find that family ownership is not a significant variable under the $95 \%$ confident interval and the coefficient is positive. This may be because the change in market and economic conditions from 2003 to 2021; the industry difference in selected companies and the difference in sample capacity (30 rather than 252).

Finally, by comparing the different conclusions of Anderson et al. [10] and Villalonga and Amit [4], we notice that the relationship between family ownership and capital structure need to be precisely discussed. More family ownership's elements need to be included in the discussion. In the future study, we can continually to research this topic by using broader dataset. Or, focusing on finding more common factors of family ownership to discuss how different elements may influence company's capital structure in different ways.

\section{REFERENCES}

[1] Anderson, R. C., Mansi, S. A. \& Reeb, D. M. (2003) Founding family ownership and the agency cost of debt. Journal of financial economics, 68(2), 263285.

[2] Villalonga, B. \& Amit, R. (2006) How do family ownership, control and management affect firm value?. Journal of financial Economics, 80(2), 385417.

[3] Medeicros, C. (2015) Can family ownership influence firms' capital structure decisions?. MSc. Universidade Católica Portuguesa.

[4] Shleifer, A. \& Vishny, R. W. (1986) Large Shareholders and Corporate Control. The Journal of political economy, 94(3), 461-488.

[5] Barth, E., Gulbrandsen, T. \& Schønea, P. (2005) Family ownership and productivity: the role of owner-management. Journal of corporate finance (Amsterdam, Netherlands), 11(1), 107-127.

[6] Anderson, R. C. \& Reeb, D. M. (2003) FoundingFamily Ownership and Firm Performance: Evidence from the S\&P 500. The Journal of finance (New York), 58(3), 1301-1328.

[7] Andres, C. (2008) Large shareholders and firm performance-An empirical examination of founding-family ownership. Journal of corporate finance (Amsterdam, Netherlands), 14(4), 431-445.

[8] Maury, B. (2006) Family ownership and firm performance: Empirical evidence from Western European corporations. Journal of corporate finance (Amsterdam, Netherlands), 12(2), 321-341.

[9] Myers, S. C. \& Majluf, N. S. (1984) Corporate financing and investment decisions when firms have information that investors do not have. Journal of Financial Economics, 13(2), 187-221.

[10] Ramalho, J. JS., Rita, R. MS. \& da Silva, J. V. (2018) The impact of family ownership on capital structure of firms: Exploring the role of zero-leverage, size, 
location and the global financial crisis. International small business journal, 36(5), 574-604.

[11] Duffie, G. (1998) The relationship between treasury yields and corporate bond yield spreads. Journal of Finance, 103, 2225-2241.

[12] Reeb, D., Mansi, S. \& Allee, J. (2001) Firm internationalization and the cost of debt financing: evidence from non-provisional publicly traded debt. Journal of Financial and Quantitative Analysis, 36, $395-414$ 